\title{
Effect of Poultry Production on Agricultural Production in Nigeria
}

\author{
Ewubare, Dennis Brown ${ }^{1}$ \\ Ozar, Vivian² ${ }^{2}$ D
}

${ }_{1,2}^{12}$ Department of Agricultural and Applied Economics, Rivers State University, Port Harcourt, Nigeria

'Emailidenniserwbare@yahoo.com Tel: 08037068750

2Emailivivianozah@gmail.com Tel: 08064365944

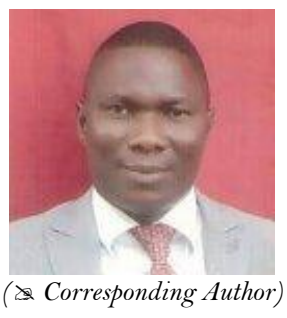

\begin{abstract}
This study examined the effects of poultry production on agricultural output in Nigeria. Specifically, this study is tailored to explore the effects of poultry birds' production, poultry eggs production and poultry meat production on agricultural output. The period covered by the study spanned from 1975 to 2016. Data on the variables of interests were obtained from the Food and Agricultural Organization Statistics (FAOSTAT) and National Bureau of Statistics. The analytical techniques comprise OLS and error correction model. The Phillips-Perron unit root test results show that all the variables have unit root at levels test, but become stationary after being differenced once. The cointegration test results indicate that each of the test statistics show evidence of two cointegrating equations. This suggests that in actual fact long run relationship exists among the variables. From the parsimonious ECM, it was revealed that poultry birds production negatively influence agricultural GDP. Poultry eggs production has an insignificant effect on agricultural GDP as evidenced in the parsimonious ECM. The result further shows that poultry meat production is associated with a positive and significant coefficient. The implication of this finding is that the production of poultry meats enhances agricultural GDP through its important contribution to the livestock sub-sector. It was discovered from the result that the coefficient (-0.378) of error correction has the intended theoretical negative sign and also satisfies the statistical condition at 1 percent level. It is clear from this finding that any short run disequilibrium in the system can be corrected in the long run at 39 percent. Thus, this study recommends amongst others that governments at all levels should evolve measures that promote huge commitment to infrastructural development in agricultural sector in order to boost poultry output and promote self-sufficiency in poultry farming.
\end{abstract}

Keywords: Poultry production, Agricultural output, Livestock.

Citation | Ewubare, Dennis Brown; Ozar, Vivian (2018). Effect of Poultry Production on Agricultural Production in Nigeria. Economy, 5(1): 8-16.

History:

Received: 16 April 2018

Revised: 28 May 2018

Accepted: 31 May 2018

Published: 4 June 2018

Licensed: This work is licensed under a Creative Commons

Attribution 3.0 License (c) $)$ E

Publisher: Asian Online Journal Publishing Group
Contribution/Acknowledgement: Both authors contributed to the conception and design of the study.

Funding: This study received no specific financial support

Competing Interests: The authors declare that they have no conflict of interests.

interests. Transparency: The authors confirm that the manuscript is an honest,
accurate, and transparent account of the study was reported; that no vital features of the study have been omitted; and that any discrepancies from the study as planned have been explained.

Ethical: This study follows all ethical practices during writing.

\section{Contents}

1. Introduction

2. Literature Review

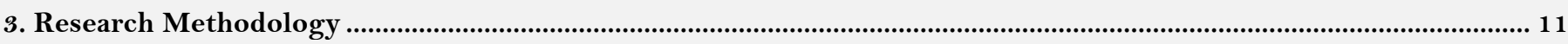

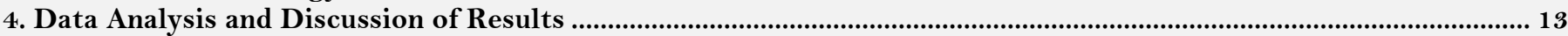

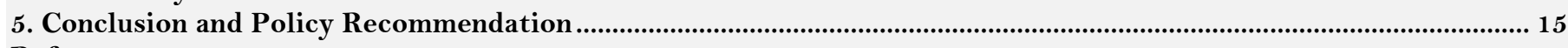

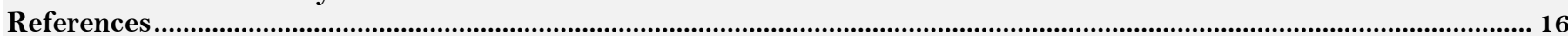




\section{Introduction}

In Africa, agriculture has remained at the forefront of economic activities, thus, accounting for 30 percent of the national income (Heise et al., 2015) and large proportion of the overall exports. For this reason, both public and private concerns in the agricultural sector continue to increase. According to Connolly (2014), about three-quarters of the total population in Africa depend on agriculture for livelihood and the demand for various agriculture products has continued to increase in recent years. With the increase in the disposable income of the population, the demand for agricultural produce especially poultry products (eggs and meat) has continued to increase across the African Continent.

The popularity of poultry birds in Nigeria is noteworthy and can be attributed to the numerous benefits associated with poultry production and other value chain. Heise et al. (2015) argue that poultry birds are good sources of protein either used as eggs or meat. They further explained that the production of poultry birds is relatively cost effective, thus, making it possible for low income farmers to start up the business. More so, the return on poultry investment is relatively high compared to other livestock production and the high level of acceptability of the poultry meat across diverse ethnic backgrounds and religious beliefs broadens the market share and makes the business very viable. In addition to the benefits created by the poultry meat, Ojo (2003) and Aboki et al. (2013) remarked that poultry eggs are more affordable for low income earners compared to other sources of protein. This adds to the relative importance of poultry to agriculture.

The distribution of poultry production across the six geo-political zones in Nigeria as provided by the Presidential Committee on Livestock (PCOL) (2003) include 17.8million birds, 15.8 million birds and 22.6million birds in the northwest, northeast and north central zones respectively while the south-east, south-south and southwest geo-political zones have 16.0million birds, 15.2 million birds and 24.3million birds respectively. The production estimates of poultry birds on report indicate that between 1998 and 2003, 179,667 metric tonnes of meat was produced while 434,000 metric tonnes of eggs was produced in Nigeria. In spite of the positive spill-over effects associated with poultry production, the output hardly meets the growing demand. This is because consumption increases rapidly than output. Rotschild (2002) posits that the domestic production shortfall is estimated at 25,000 metric toones. Thus, increasing importation undermines exchange rate stability and external reserve build-up.

The shortfall in poultry production amidst the growing demand has remained key challenges as it reduces the net-marginal contribution of this livestock segment to the agricultural output. This lag in poultry production has remained major source of worry to the government and other relevant stakeholders in the agricultural sector. The current level of food insecurity calls for well-defined approaches in meeting the desired objectives. One of the generally adopted approaches is increased production and productivity of the poultry sub-sector. Increasing productivity and efficiency within the agricultural sector, particularly among small-scale poultry egg producers require a good knowledge of the current efficiency or inefficiency inherent in the subsector as well as factors responsible for this level of efficiency or inefficiency. This is because despite the growth in egg and meat production industry since year 2000 in Nigeria (Tijjani et al., 2006), growing local demand has not matched the fluctuating local supply. It therefore, becomes imperative to gain more insight into the challenges and problems confronting poultry production and how poultry production contributes to agricultural GDP in Nigeria. It is against this backdrop that this study explored the effects of poultry production on agricultural output in Nigeria over the period of 42 years (1975-2016).

\section{Literature Review}

\subsection{Theoretical Framework}

\subsubsection{Input-Output Theory}

The input-output theory is credited to Leontief (1951). The theory focused on inter-industry relations and interrelationship in the economy wide aggregate as the input of one industry is the output of another industry. The theory was originally developed to analyze and measure the connection that exists between key sectors of an economy. The theory has been extended to include smaller systems of the economy, and on the broader scale, the economic relationship between countries. The theory argues that, the various sectors of the economy are interdependent as the output of a particular sector forms the input of another sector. The substructure of the inputoutput (I-O) analysis incorporates input-output tables. Each table showcases the supply chain of inputs as expressed in rows and columns. The input-output model is instrumental in estimating three important type of impacts: direct, indirect and induced.

By employing the I-O model, poultry farmers could be able to estimate adjustment or changes in inputs used by them due to a change in output in one or more specific sector. The direct consequence of this would be the adjustment in money balance expended by them. The secondary consequence of this relates to the number of labour hired by the suppliers of input utilized by the poultry farmer. The induced impact comes from the workers or suppliers purchasing more goods and services. The input-output theory has been criticized on the grounds of its rigidity as it fails to reflect certain phenomena such as increasing costs, bottlenecks, etc. Also, the lack of mechanism for price adjustments in the model makes it unrealistic.

\subsubsection{Theory of Production}

The production theory concerns itself with the economic process that describes how certain specific inputs are jointly combined to produce a given level of output. The production theory has its footing in the works of the neoclassical economists. The neoclassicals argued that the economy comprises of two important agents - the consumer and producer. The former engages in consumption activities whilst the latter undertakes production activities. These decisions or activities taken by the aforementioned agents are considered inseparable owing to the fact that the decision bothering on consumption, labour supply, and production are looked at simultaneously through the behavioural lens of three key agents: consumers, workers, and producers (Mankiw, 2015). 
The cradle of this theory kicks starts from the poultry farmer making decisions on the number of labour to be utilized or employed in the course of his/her poultry farming activities; whether or not to utilize purchased labour or make do with self labour; the amount of capital to be invested into the poultry business; the source of capital (personal savings or loans from deposit money banks); the skills, talents and creativity inherent in the owner of the enterprise or the labour to be employed or currently employed, among others. These decisions shape the configuration of inputs to be utilized and quantum of output to be realized. What this exhumes is that, the poultry farmer can vary the level and composition of his or her farm inputs and outputs.

In practical sense, poultry farmers tend to have a variety of goals ranging from income instability, ensuring household food security, achieving certain consumption preferences and giving back to his or her community. In achieving these, poultry farmers must produce the highest number of output given available or devoted resources as revenue depends on the level of output and the unit price of the output. However, the achievement of the highest level of output is limited by certain constraints that engulfs availability of capital, land being fixed in supply, the composition of labour in terms of quality, price, and availability.

The behaviour of the poultry farmer as it borders on how resources can be best allocated so as to ensure the achievement of the highest level of output can be best scripted using the theory of cost minimization and output maximization. Farmers venturing into or engaged in poultry farming, like any other entrepreneur, are assumed to maximize total output, minimize production cost, or engage in both. In other to achieve any or both of the stated objectives (maximization or minimization), the poultry farmer sets out to maximize a set of utility subject to certain input constraints as defined by the set of utility subject to certain input constraints as defined by the production function. The poultry farmer derives satisfaction from the quantities of output (from instance broilers, layers, poultry-egg) produced subject to the input combination, with the latter dependent on each input's price, the prices of other inputs, and other sets of socio-economic variables.

\subsection{Conceptual Framework}

Poultry are chickens, ducks, geese, guinea fowls, turkeys and other related birds kept for meat and egg. In Nigeria, the poultry population is estimated to be 140 million (Ocholi et al., 2006). They are the most commonly kept livestock and over $70 \%$ of those keeping livestock are reported to keep chickens (Amar-Klemesu and Maxwell, 2000). Chickens have its scientific name to be Gallus domestics and it is one type of poultry. It belongs to the family phasiendae and it is estimated to be about $69 \%$ of the total number of birds kept in Nigeria (Sonaiya, 1990). Commercial poultry systems are industrialized and, therefore, based on large, dense, uniform stocks of modern poultry hybrids. However, most of the poultry is still kept in rural production systems, which are characterized by insufficient hygiene management. Even though many farmers would like to stock hybrids, which gain weight more quickly and are more disease resistant, their high mortality rates make hybrid production less profitable (Esiobu et al., 2014). Additionally, farm and flock size correlates significantly to the output of poultry farms. Large farm size increases productivity as well as technical, allocative, and resource use efficiency (Esiobu et al., 2014). Many poultry farmers still work at a subsistence, small, or medium-sized level mainly due to limited financial resources (Aboki $e t$ al., 2013).

\subsection{Empirical Literature}

Hamid et al. (2017) examined the performance of the poultry industry in Bangladesh focusing on the contribution of private sector for the development and marketing of poultry products. The study also investigated the problems and constraints of poultry industry and the scope and opportunity cost of poultry industry. This investigation is mirrored through various programs designed and implemented by private enterprises in the poultry industry. The method of analysis dwelled on descriptive statistics with a focus on frequency distribution and simple percentage. The result shows that the availability of meat and egg is much lower than the demand, thus a creating a condition of deficit in the market system. Specifically, the study revealed that the contribution of poultry meat to the total meat products is about 35.2 percent whereas egg production is 63.65 percent of the total domestic demand. In comparative terms, the study showed that the per capita poultry meat consumption is much lower compare to other Asian countries as it averaged 1.9 kilogram. Based on the findings, the study recommended for synergy between private sector and the government as well as foreign investment in order to boost production in the livestock industry.

Bamiro (2008) analyzed the economic importance of poultry production in some sampled local government areas in Oyo state, Nigeria. The sampling technique employed by the study in selecting the study area and 71 respondents is purposive in nature. The method of analysis involved combinations of descriptive statistics and multiple regressions. It was uncovered from the result that the profitability of poultry farmers depends largely on enterprise combinations and extent of production. It was evident from the budgetary analysis that enterprises that operate in a large scale have highest turnover compared to those that operate relatively on low scale. The descriptive analysis also show that poultry farmers engaged in eggs production have highest gross margin compared to those engaged in broiler production. Thus, egg production contributes more to agricultural GDP. The result of regression analysis revealed that poultry birds, feed and labour size are key drivers of productivity in the poultry sub-sector and by extension the overall agricultural sector. Owing to the findings, the study recommends that poultry farmers should focus more on egg production in order to boost the contribution of the poultry industry to agricultural GDP.

Yusuf et al. (2016) used primary data collected through the instrumentality of questionnaire in exploring the economics of poultry production in Kwara State, Nigeria. They made use of the budgetary and profit index analysis. A structured questionnaire was administered to 80 registered poultry farmers selected using the systematic random sampling technique. Obtained data were analyzed using descriptive statistics, benefit cost ratio, ordinary least squares regression and the budgetary analysis. Empirical findings of the study disclosed that, commercial poultry farmers in Kwara State are well educated, highly experienced and young with a keen interest in the business of poultry farming. Upon analyzing the costs and returns, the findings showed that poultry farming is profitable in the study area as the gross income and net income for egg production were computed to be 
$\mathrm{N} 4,062,422$ and $\mathrm{N}$ 1,255,965 respectively, whilst that of broiler productions were found to be $\mathrm{N} 1,683,209$ and N499, 187 respectively. The outcome of the regression analysis carried out disclosed that, labour, equipment, feed, and stock capacity are significant facts that affects poultry farming in the study area.

Ayieko et al. (2014) sort to calculate the profit of indigenous chicken in Makueni County and to determine the association that exists amongst certain socio-economic factors and profit from IC. The multistage sampling was used and this gave birth to a sample size of 130 households to which structured questionnaires were administered to. With the growing usage of software applications in the analysis of data, STATA 11 was employed in carrying out both budgetary analysis and multiple regression analysis. The empirical findings of the study divulged that, the profit from the production of IC in Makueni was ksh. 5347 per 100 birds. On the socio-economic factors that has significant association with profit, the factors identified by the study includes: flock size, age, access to credit, education, and price and year in farmer group.

Ezeh et al. (2012) measured the technical efficiency and its determinants in the production of broilers in Umuahia capital territory of Abia State, Nigeria. Using a multistage sampling technique, the sample size for the study is 60 poultry farmers. The study employed a stochastic production function. The employed production function brought to bear feed intake, stock-size, and labour input as critical variables that influences the output of farmers. The farm level technical efficiency, it was discovered, ranged from $87 \%$ to $97 \%$ with an average of $75 \%$. The determinants of the farm level technical efficiency were household size, extension contact, age and the level of education.

Assessed constraints to increased layers production among small-scale poultry farmers in Ibadan Area of Oyo State, Nigeria. The study made use of a multistage sampling technique which gave rise to 120 small scale poultry farmers to which structured questionnaires were administered to. The instrument for data analysis is pairwise correlation coefficient. Empirical findings of the study divulged that, disease and pest attack ranked top as constraints faced by the sampled farmers in carrying out their productive activities and these was accompanied by difficulty in the procurement of credit and loan. The results of the correlation analysis revealed a significant association between number of birds raised, income from sale of egg, and constraints to increased layers production among farmers involved in small-scale poultry farming. Hinging on the discoveries of the study, it was proposed that government tackle the problems associated with the procurement of credits and loans, and ensuring stability in price.

Emokaro et al. (2016) carried out a study to analyze the economics of backyard poultry farming in Benin city. The sampling technique adopted for their work was the snowball sampling technique which produced the ninetysix (96) backyard poultry farmers that formed the sample size for the study. Primary data were employed for the study with the needed data obtained through the issuance of a structured questionnaire. Descriptive statistics, profitability measures and multiple regression analysis were used in analyzing the obtained data gotten from responses as captured by the issued questionnaire. The empirical findings of the study points to the dominance of layers poultry production in the business of backyard poultry farming with it (layers) attracting $70 \%$ of all poultry business. The profitability analysis divulged the poultry business is a profitable one in Benin city averaging a positive gross margin of N573,346.01 yearly. Results of the regression analysis conducted lay bare the positive contribution of family size and farming experience to net returns from engaging in backyard farming. Conversely, the age of respondents was uncovered to negatively influence a farmers' net income. On soliciting for hurdles or constraints faced by farmers, insufficient finance and high cost of feed were thrown into the open as limiting factors.

Ume et al. (2016) examined the economics of Broiler production among rural women in Imo State. The study area focused on Ahiazu Mbaise local government area. A sample size of 200 rural women engaged in broiler farming was selected using a combination of both purposive and multi-stage sampling technique. A structured questionnaire was employed in soliciting for responses that formed the data relied upon and used for the study. In ensuring the achievement of outlined objectives, the gross margin analysis and percentage response techniques were used in analyzing obtained data. The outcome of the analysis carried out disclosed that, the gross margin for

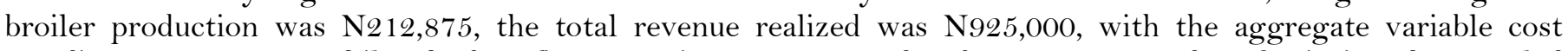
standing at N712,125; whilst the benefit cost ratio was computed to be N1:1.2. In order of priority, the sampled farmers identified poor marketing price, expensive labour wage, poor access to credit, and pest and disease as constraining factors to their broiler production.

Nwandu et al. (2016) applied descriptive statistics in appraising the potentiality of poultry production as a means of livelihood and poverty alleviation among its farmers in Nigeria. As part of the objectives, the study examined the profitability approaches for successful operation of poultry business. The findings revealed that poultry production business in its entire ramification is undoubtedly one of the viable farming enterprises providing the much needed animal protein sources, especially egg and meat in order to provide solution to food crisis in Nigeria in terms of protein deficiency. In view of the findings, the study therefore, recommended that the government should prioritize poultry production business as a means of empowering the teeming population of the youths in order to check the growing rate of unemployment and boost agricultural productivity.

\section{Research Methodology \\ 3.1. Research Design}

In view of the nature of this study, ex-facto research design was employed for this study. This is because this study is based on existing data which were documented over the past 42 years (1975-2016).

\subsection{Types and Sources of Data Collection}

This study focused mainly on secondary data. The data were collected on annual basis from 1975 to 2016 and the source for the indicators of poultry production is Food and Agricultural Organization Statistics (FAOSTAT). In addition to this, data on agricultural output over the sampled period were collected from the National Bureau of Statistics. 


\subsection{Method of Data Analysis}

This study relied on the OLS techniques for estimating the effects of the underlying indicators of poultry production on agricultural output in the long run. The choice of this method stems from its attribute as the Best Linear Unbiased Estimator (BLUE). As the best estimator, the OLS estimates are preferred to estimates from other econometrics methods. More importantly, the Error Correction Model (ECM) is applied to estimate the short-run behaviors of the measures of poultry production and the speed at which the model adjusts to equilibrium in the long run. Before estimating the long run and short behaviors of the variables, the data were be subjected to unit root and cointegration tests. Again, the estimated model was subjected to some diagnostics tests which focused mainly on higher order serial correlation test, heteroscedasticity test and normality test amongst others. Each of these tests is discussed below:

\subsubsection{Pre-Estimation Tests}

i. Unit Root Test: The time series characteristics of the variables were ascertained via stationarity test process. Specifically, this test is applied to ensure that each of the variables does not enter the model in an explosive manner (non-stationary status). The Phillips and Perron (1988) method, an alternative procedure to the popular Augmented (Dickey and Fuller, 1981) approach was adopted for the unit root test. The null hypothesis of a unit root (non-stationarity) was tested against the alternative hypothesis of no unit root (stationarity) at 5 percent level. The model for the unit root test is formalized below:

$$
\Delta Q_{\mathrm{t}}=\propto_{0}+\propto_{1} Q_{\mathrm{t}-1}+\sum_{i=1}^{K} \beta_{i} \Delta Q_{\mathrm{t}-\mathrm{i}}+\lambda_{\mathrm{t}}
$$

Where: $Q_{t}=$ variables included in the model, $\quad \propto_{1}$ and $\beta_{\mathrm{i}}=$ parameter estimates, $\mathrm{K}=$ length of lag, $\Delta=$ First difference operator, $\lambda_{t}=$ Random disturbance term

It is expected that each of the series be integrated of order zero $[\mathrm{I}(0)]$ for the OLS to be efficient and unbiased. However, a deviation from the expected stationarity process may yield a spurious result.

\section{ii. Cointegration Test}

Before estimating the error correction model, the series was subjected to cointegration test to determine whether their linear combinations lead to long run relationship. Evidence of long run among the underlying series shall prompt the estimation of the error correction coefficient in order to capture the speed of adjustment. Owing to its robustness, the Johansen system of cointegration test for multivariate models proposed by Johansen and Juselius (1990) is applied in ascertaining the presence of a long-run relationship among the variables. The algebraic formalization of the Johansen-Juselius cointegration model based on the required test statistics is as follows:

$$
\begin{gathered}
J_{\text {trace }}(r)=-T \sum_{i=r+1}^{n} \operatorname{In}\left(1-\hat{\lambda}_{i}\right)(3.2) \\
K_{\max }(r, r+1)=-T \operatorname{In}(1-\hat{\lambda} r+1)(3.3)
\end{gathered}
$$

Where $\mathbf{J}=$ estimated values of the characteristics roots of the trace statistics estimated from the cointegrating vector.

$k=$ estimated values of the characteristics root of the Maximum-Eigen statistics estimated from the cointegrating vector

$T=$ number of observations.

For the trace test, the null that the number of distinct cointegrating vectors is equal to or less than $r$ is tested at 5 percent level. On the other hand, the Max-Eigen statistic shall test the null hypothesis that the number of cointegrating vectors is $r$, against the alternative of that it is $r+1$. The critical values for each of these test statistics as provided by Johansen and Juselius (1990) shall be compared with the computed values at 5 percent critical value. Evidence of at least one cointegrating equation at selected 5 percent level of test implies that long run relationship exists among the series.

\subsection{Model Specification}

This study developed and estimated a single multivariate model to capture the production-output relationship between the indicators of poultry production and growth of agricultural sector. The functional specification of the relationship between agricultural output (APO) and the measures of poultry production such as stock of poultry birds (POB), eggs production (EPO) and poultry meat production (PMP) is as follows:

Where: APO = agricultural output

$$
\mathrm{APO}=\mathrm{f}(\mathrm{POB}, \mathrm{EPO}, \mathrm{PMP})
$$

$\mathrm{POB}=$ stock of poultry birds

$\mathrm{EPO}=$ eggs production

$\mathrm{PMP}=$ poultry meat production

The linear and non-linear econometric models of Equation (3.4) are provided as:

$$
\begin{aligned}
& \mathrm{APO}_{\mathrm{t}}=\mathrm{N}_{\mathrm{o}}+\mathrm{N}_{1} \mathrm{POB}_{\mathrm{t}}+\mathrm{N}_{2} \mathrm{EPO}_{\mathrm{t}}+\mathrm{N}_{3} \mathrm{PMP}_{\mathrm{t}}+\mathrm{U}_{1 \mathrm{t}} \\
& \mathrm{InAPO}_{\mathrm{t}}=\mathrm{M}_{\mathrm{o}}+\mathrm{M}_{1} \mathrm{InPOB}_{\mathrm{t}}+\mathrm{M}_{2} \operatorname{InEPO}_{\mathrm{t}}+\mathrm{M}_{3} \operatorname{InPMP}_{\mathrm{t}}+\mathrm{U}_{2 \mathrm{t}}
\end{aligned}
$$

Where: APO, POB, EPO and PMP are as explained in Equation (3.4).

$\mathrm{N}_{0}$ and $\mathrm{M}_{0}=$ intercepts or constant parameters

$\mathrm{N}_{1}-\mathrm{N}_{3}$ and $\mathrm{M}_{1}-\mathrm{M}_{3}=$ slope parameters

In = natural $\log$ notation

$\mathrm{U}_{1 \mathrm{t}}-\mathrm{U}_{2 \mathrm{t}}=$ stochastic term

Equations (3.5) and (3.6) respectively depict the linear and non-linear econometric models. 
The a priori expectations require that the coefficients of each of the poultry products should have a positive sign. This is because increase in poultry production is expected to boost agricultural output and thus, increase its share of GDP. Based on this premise, the expected signs of the coefficients of the explanatory variables are expressed algebraically as: $\mathrm{N}_{1}>0, \mathrm{~N}_{2}>0, \mathrm{~N}_{3}>0, \mathrm{M}_{1}>0, \mathrm{M}_{2}>0$, and $\mathrm{M}_{3}>0$.

The short run dynamic behaviors of the explanatory variables are captured using an error correction model (ECM) and the model is expressed as:

$$
\begin{gathered}
\Delta I n A P O_{t}=\alpha_{0}+\sum_{i=1}^{y} \alpha_{1} \Delta I n A P O_{t-1}+\sum_{i=1}^{y} \alpha_{2} \Delta I n P O B_{t-1}+\sum_{i=1}^{y} \alpha_{3} \Delta I n E P O_{t-1}+\sum_{i=1}^{y} \alpha_{4} \Delta I n P M P_{t-1} \\
\sum_{i=1}^{y} \alpha_{5} \Delta \operatorname{InSOC}_{t-1}+\Phi E C M_{t-1}+e_{t} 3.7
\end{gathered}
$$

Where: $\alpha_{0}=$ Constant parameter, $\alpha_{1}-\alpha_{4}=$ short-run dynamic coefficients of the regressors, $\mathrm{y}=$ length of lag, $\mathrm{ECM}=$ Error correction term lagged for one period, $\Phi=$ error correction coefficient lagged for one period, $\mathrm{e}_{1 \mathrm{t}}=$ Random disturbance term.

\subsection{Description of Variables in the Model}

\section{A. Dependent Variable}

i. Agricultural output (APO): This refers to crops, livestock, fisheries and forestry products produced in Nigeria over a period of time usually per annum. It excludes all kinds of agricultural produce and allied products imported to Nigeria from the rest of the world. The output of agricultural sector in the Nigerian economy between 1975 and 2015 as reported by the National Bureau of Statistics shall serve as the dependent variable for this study.

\section{B. Explanatory Variables}

i. Stock of poultry birds (POB): These comprise domestic fowls such as chickens, turkeys, ducks, geese, pigeons and recently ostriches reared with the primary objective of producing meat and eggs. They are important sources of protein and play key roles in boosting food security. Increase in the sock of poultry birds is expected to stimulate agricultural output.

ii. Eggs production (EPO): This involves the raising of chickens, especially layers for eggs production which important source of protein. It is expected that increase in eggs production will increase agricultural GDP.

iii. Poultry meat production (PMP): This refers to broilers and other types of poultry meat produced domestically for meeting consumption and in some instances export needs. It is expected that increase in the production of poultry meat will contribute positively to agricultural output. Data on the total number of poultry produced over the sampled period shall be sourced from the FAO statistics.

\section{Data Analysis and Discussion of Results}

\subsection{Descriptive Statistics}

As part of efforts to provide more information on the distribution of each of the series over the period covered, the descriptive statistics of the series are reported in Table 4.1.

\begin{tabular}{l|l|l|l|l}
\multicolumn{9}{c}{ Table-4.1. Descriptive statistics for the series } & PMP \\
\hline Mean & APO & POB & EPO & 171631.9 \\
\hline Median & 19378590 & 121776.4 & 384362.0 & 169500.0 \\
\hline Maximum & 930328.1 & 124310.0 & 393500.0 & 273000.0 \\
\hline Minimum & $2.54 \mathrm{E}+08$ & 192313.0 & 660000.0 & 82000.00 \\
\hline Std. Dev. & 6028.330 & 64380.00 & 150000.0 & 46397.60 \\
\hline Observations & 51719054 & 31592.73 & 156520.0 & 42 \\
\hline
\end{tabular}

The average values of APO, POB, EPO and PMP as observed from the descriptive statistics are 19378590 million, 121776.4 tonnes, 384362.0 tonnes and 171631.9 tonnes respectively. From the respective standard deviation of the series, it was found that the observations for the variables do not converge around their mean values. This inference is based on the fact the respective standard deviations for the variables are more than the associated mean values.

\subsection{Ordinary Least Squares based Static Model}

The static regression model estimated using OLS as showed in Table 4.2

The regression model was estimated using OLS as reported in Table 4.2 reveals that poultry eggs production is positive related to changes in agricultural output. 10 percent increase in poultry eggs production generates 68.9 percent increase in agricultural output, indicating that poultry eggs production is a source of increasing returns to scale in agricultural GDP. However, stocks of poultry birds and poultry meat production are not significant in explaining changes in agricultural output. However, the entire model shows evidence of statistical significance, thus indicating that the regressors are jointly significant. Although the R-squared (0.875) attests to the high explanatory power of the regressors, the Durbin-Watson statistics (0.753) shows that there is serial correlation in the model. This econometric problem of serial correlation observed in the model can be as a result of unit root in the series, thus constraining any long term prediction based on the regression outcome. This provoked the test for unit root in the series 
Table-4.2. OLS based regression result

\begin{tabular}{|c|c|c|c|c|}
\hline \multicolumn{5}{|c|}{ Dependent Variable: LOG(APO) } \\
\hline \multicolumn{5}{|c|}{ Method: Least Squares } \\
\hline Variable & Coefficient & Std. Error & t-Statistic & Prob. \\
\hline $\operatorname{In}(\mathrm{POB})$ & -1.012 & 4.519 & -0.224 & 0.823 \\
\hline $\operatorname{In}(\mathrm{EPO})$ & 6.899 & 1.155 & 5.969 & 0.000 \\
\hline $\operatorname{In}(\mathrm{PMP})$ & 0.647 & 4.156 & 0.155 & 0.877 \\
\hline $\mathrm{C}$ & -70.735 & 9.388 & -7.534 & 0.000 \\
\hline R-squared & 0.875 & & & \\
\hline Adjusted R-squared & 0.865 & \multicolumn{2}{|c|}{ Durbin-Watson stat } & 0.753 \\
\hline F-statistic & 89.09 & & & \\
\hline Prob(F-statistic) & 0.000 & & & \\
\hline
\end{tabular}

\subsection{Unit Root Test}

The Philips-Perron (PP) procedure to stationarity was applied in testing whether or not the variables are stationary or not at 5 percent level. The results are displayed Table 4.3.

Table-4.3. Philips-Perron (PP) test results

\begin{tabular}{l|l|l|l|l|l}
\hline Variable & PP levels test results & PP 1 $\mathbf{1}^{\text {st }}$ difference test results & Order of integration \\
\hline & Adjusted t-stat. & $\mathbf{5 \%}$ critical value & Adjusted t-stat. & $\mathbf{5 \%}$ critical value & \\
\hline $\mathrm{In}(\mathrm{APO})$ & 0.780 & -2.935 & -13.763 & -2.936 & $\mathrm{I}(1)$ \\
\hline $\mathrm{In}(\mathrm{POB})$ & -2.332 & -2.935 & -6.876 & -2.936 & $\mathrm{I}(1)$ \\
\hline $\mathrm{In}(\mathrm{EPO})$ & -2.086 & -2.935 & -6.648 & -2.936 & $\mathrm{I}(1)$ \\
\hline $\mathrm{In}(\mathrm{PMP})$ & -2.740 & -2.935 & -6.988 & -2.936 & $\mathrm{I}(1)$ \\
\hline
\end{tabular}

Source: Compiled by the Author as computed from E-Views software

NB: In denotes natural log transformation

The results as showed in Table 4.3 revealed that none of the variables is stationary at levels. This is because their adjusted t-statistics are less than their associated critical values at 5 percent level. Following the nonstationarity of the variables at levels, transformation of the variables via 1 st differencing was carried out. The result shows evidence of stationarity upon 1st differencing. The implication of this finding is that all the variables are integrated of order one. This makes the Johansen cointegration variety appropriate for testing if the variables show any evidence of long run relationship.

\subsection{Cointegration Test}

The cointegration test proposed by Johansen and Juselius was applied in examining if long run relationship exists among the series or not. The results are reported in Table 4.4.

Table-4.4. Results of cointegration test

\begin{tabular}{|c|c|c|c|c|}
\hline \multicolumn{4}{|c|}{ Series: $\operatorname{In}(\mathrm{APO}) \operatorname{In}(\mathrm{POB}) \operatorname{In}(\mathrm{EPO}) \operatorname{In}(\mathrm{PMP})$} & \\
\hline \multicolumn{5}{|c|}{ Lags interval (in first differences): 1 to 2} \\
\hline Hypothesized No. of CE(s) & Eigenvalue & Trace Statistic & 0.05 Critical Value & Prob.** \\
\hline None $*$ & 0.579 & 66.960 & 47.856 & 0.000 \\
\hline At most $1 *$ & 0.430 & 33.166 & 29.797 & 0.019 \\
\hline At most 2 & 0.182 & 11.234 & 15.494 & 0.197 \\
\hline At most 3 & 0.083 & 3.382 & 3.841 & 0.065 \\
\hline Hypothesized No. of CE(s) & Eigenvalue & Max-Eigen Statistic & 0.05 Critical Value & Prob.** \\
\hline None $*$ & 0.579 & 33.794 & 27.584 & 0.007 \\
\hline At most $1^{*}$ & 0.430 & 21.932 & 21.131 & 0.038 \\
\hline At most 2 & 0.182 & 7.851 & 14.264 & 0.394 \\
\hline At most 3 & 0.083 & 3.382 & 3.841 & 0.065 \\
\hline
\end{tabular}

Source: Compiled by the Author as computed from E-Views software

* and In respectively implies rejection of the hypothesis at the 0.05 level and natural log transformation.

In compliance with the econometric requirements for verifying the stationarity properties of the series and estimating the error correction model, cointegration test was undertaken at 5 percent level. The results indicate that both the Trace and Maximum Eigenvalue statistics confirm that two cointegrating equations exist in the model. In other words, the variables are cointegrated and the dynamic relationship among them can be represented as an ECM.

\subsection{Error Correction Model}

The error correction model was estimated to provide better information on the dynamic relationship between the dependent and the predictor variables. The result of its parsimonious representation is reported in Table 4.5. 


\begin{tabular}{|c|c|c|c|c|}
\hline \multicolumn{5}{|c|}{ Dependent Variable: DLOG(APO) } \\
\hline \multicolumn{5}{|c|}{ Method: Least Squares } \\
\hline Variable & Coefficient & Std. Error & t-Statistic & Prob. \\
\hline $\operatorname{ECM}(-1)$ & -0.378 & 0.076 & -4.979 & 0.000 \\
\hline $\mathrm{C}$ & 0.522 & 0.073 & 7.072 & 0.000 \\
\hline $\mathrm{DIn}(\mathrm{APO}(-1))$ & 0.116 & 0.113 & 1.019 & 0.318 \\
\hline $\mathrm{DIn}(\mathrm{APO}(-2))$ & -0.442 & 0.091 & -4.862 & 0.000 \\
\hline $\mathrm{DIn}(\mathrm{POB})$ & -1.048 & 1.093 & -0.958 & 0.347 \\
\hline $\operatorname{DIn}(\operatorname{POB}(-1))$ & -3.098 & 0.699 & -4.426 & 0.000 \\
\hline $\operatorname{DIn}(\operatorname{POB}(-2))$ & -3.975 & 0.747 & -5.318 & 0.000 \\
\hline $\mathrm{DIn}(\mathrm{POB}(-3))$ & 2.299 & 1.232 & 1.865 & 0.074 \\
\hline $\mathrm{DIn}(\mathrm{EPO})$ & -0.231 & 0.401 & -0.577 & 0.569 \\
\hline $\mathrm{DIn}(\mathrm{EPO}(-1))$ & -2.422 & 0.588 & -4.114 & 0.000 \\
\hline $\operatorname{DIn}(\mathrm{EPO}(-2))$ & -1.785 & 0.500 & -3.569 & 0.001 \\
\hline $\mathrm{DIn}(\mathrm{EPO}(-3))$ & -2.042 & 0.525 & -3.888 & 0.000 \\
\hline $\mathrm{DIn}(\mathrm{PMP})$ & 2.119 & 0.986 & 2.147 & 0.042 \\
\hline $\operatorname{DIn}(\operatorname{PMP}(-3))$ & 1.792 & 1.169 & 1.532 & 0.138 \\
\hline R-squared & 0.865 & & & \\
\hline F-statistic & 11.921 & & & \\
\hline Prob(F-statistic) & 0.000 & & & \\
\hline
\end{tabular}

It was discovered from the result that the coefficient (-0.378) of error correction has the intended theoretical negative sign and also satisfies the statistical condition at 1 percent level. It is clear from this finding that any short run disequilibrium in the system can be corrected in the long run at a speed of 39 percent. The results show that the dynamic coefficients of stocks of poultry birds are negative and significant. This implies that increasing stocks of poultry birds by 10 percent at lag 1 and 2 would respectively contract agricultural GDP by 31 percent and 39 percent. Again, poultry eggs production lagged for one, two and three periods are negatively related to agricultural output. However, it was found that poultry meat production is associated with a positive and significant coefficient. The implication of this finding is that the production of poultry meats enhances agricultural GDP through its contribution to the livestock sub-sector. Both the R-squared (0.865) and F-statistic (11.92) reveal that the model well is fitted and satisfies the statistical condition. Thus, with R-squared (0.865) exceeding the benchmark of 0.50, it implies that the explanatory variables collectively explained 87 percent variations in agricultural GDP over the period covered.

\subsubsection{Post-Estimation Tests}

The estimation of the parsimonious ECM is followed by post-estimation tests. These tests particularly focused on higher order test for serial correlation and heteroskedastic test for constant variance of the residuals. The results are showed in Table 4.5.1A and 4.5.1B.

Table-4.5.1A. Breusch-Godfrey Serial Correlation LM Test Result

\begin{tabular}{|c|c|c|c|}
\hline \multicolumn{3}{|c|}{ Breusch-Godfrey Serial Correlation LM Test: } & \multirow{2}{*}{0.2768} \\
\hline F-statistic & 1.378 & Prob. $\mathrm{F}(3,21)$ & \\
\hline Obs*R-squared & 6.251 & Prob. Chi-Square(3) & 0.1000 \\
\hline
\end{tabular}

Table-4.5.1B. Harvey Heteroskedastic Test Result

\begin{tabular}{l|l|l|l}
\hline F-statistic & 0.958 & Prob. F(13,24) & 0.5149 \\
\hline Obs*R-squared & 12.985 & Prob. Chi-Square(13) & 0.4489 \\
\hline Scaled explained SS & 11.091 & Prob. Chi-Square(13) & 0.6031 \\
\hline
\end{tabular}

In furtherance of the efforts to determine if the estimated regression parsimonious ECM model satisfies important econometrics conditions, some post-estimation tests, especially tests for serial correlation and homoscedasticity was carried out at 5 percent level. It was discovered from the test results that the model (parsimonious ECM) is not serially correlated and free of the problem of heteroskedastic. The implication of this finding is that reliable and efficient forecast can be achieved based on the outcome of the model.

\section{Conclusion and Policy Recommendation}

This study examined the place of poultry production on agricultural GDP. The findings reveal that poultry meat production contributes positively to agricultural GDP, thus stimulating aggregate output and enhancing food security. Additionally, poultry birds' population and output of poultry eggs significantly explained changes in agricultural GDP. Hence, the conclusion with regard to the findings is that the place of livestock sub-sector in meeting broad-based objective of improved productivity in the agricultural sector can be achieved through increased and sustained growth of poultry production in Nigeria. Hence, this study recommends that governments at all levels should evolve measures that promote huge commitment to infrastructural development in agricultural sector in order to boost poultry output and promote self-sufficiency in poultry farming. 


\section{References}

Aboki, E., A.A. Jongur and J.I. Onu, 2013. Productivity and technical efficiency of family poultry production in Kurmi local government area of Taraba State, Nigeria. Journal of Agriculture and Sustainability, 4(1): 52-66. View at Google Scholar

Amar-Klemesu, M. and D. Maxwell, 2000. Accra: Urban agriculture as an asset strategy. In: Supplementary income and diets, Bakker, N., Dubbeling, M., Gundel, S., Koschella, U.S and Dezeeuw, H. (Eds). Growing cities, growing food, Havana, Cuba. pp: $234-236$.

Ayieko, D.M.O., E.K. Bett and L.W. Kabuage, 2014. Profitability of indigenous chicken: The case of producers in Makueni County, Kenya. Journal of Economics and Sustainable Development, 5(11): 16-23.

Bamiro, O.M., 2008. Economic performance of commercial poultry farms in Oyo State Nigeria. International Journal Poultry Science, $7(11)$ : 1117-1121. View at Google Scholar $\mid$ View at Publisher

Connolly, A.J., 2014. A glimpse into the future: A lens through which to consider 'Africa's rising'. International Food and Agribusiness Management Review, 17(B): 9-18. View at Google Scholar

Dickey, D.A. and W.A. Fuller, 1981. Likelihood ratio statistics for autoregressive time series with a unit root. Journal of the Econometric Society, 49(4): 1057-1072. View at Google Scholar | View at Publisher

Emokaro, C.O., F.K. Akinrinmola and O.P. Emokpae, 2016. Economics of backyard poultry farming in Benin city, Edo State, Nigeria. Nigerian Journal of Agriculture, Food and Environment, 12(2): 50-57. View at Google Scholar

Esiobu, N.S., C.S. Nwosu and G.C. Onubuogu, 2014. Economics of pineapple marketing in Owerri Municipal Council Area, Imo State, Nigeria. International Journal of Applied Research and Technology, 3(5): 3 - 12. View at Google Scholar

Ezeh, C.I., C.O. Anyiro and J.A. Chukwu, 2012. Technical efficiency in poultry broiler production in Umuahia capital territory of Abia State, Nigeria. Greener Journal of Agricultural Sciences, 2(1): 00 1-007. View at Google Scholar | View at Publisher

Hamid, M.A., M.A. Rahman, S. Ahmed and K.M. Hossain, 2017. Status of poultry industry in Bangladesh and the role of private sector for its development. Asian Journal of Poultry Science, 11(1): 1-13. View at Google Scholar $\mid$ View at Publisher

Heise, H., A. Crisan and L. Theuvsen, 2015. The poultry market in Nigeria: Market structures and potential for investment in the market. International Food and Agribusiness Management Review, 18(1): 197-222. View at Google Scholar

Johansen, S. and K. Juselius, 1990. Maximum likelihood estimation and inference on cointegration-with applications to the demand for money. Oxford Bulletin of Economics and Statistics, 52(2): 169-2 10. View at Google Scholar $\mid$ View at Publisher

Leontief, W.W., 1951. The structure of the American economy 1919-1939: An empirical application of equilibrium analysis. New York: Oxford University Press.

Mankiw, G., 2015. Yes, $\mathrm{r}>$ g. So what? American Economic Review, 105(5): 43-47. View at Google Scholar |View at Publisher

Nwandu, P.I., J.A. Ojogbane, C. Okoh and F. Okechukwu, 2016. Poultry production business: A means of alleviating poverty among farmers. New York Science Journal, 9(7): 92-100.

Ocholi, R.A., I.L. Oyetunde, P. Kumblish, O. M.O. and Taama, 2006. Epidemology of an outbreak of highly pathogenic avia influenza caused by the virus subtype. Journal of Veterinary Science National Veterinary Research Institute Jos, 2(8): 1-8.

Ojo, S.O., 2003. Productivity and technical efficiency of poultry egg production in Nigeria. International Journal of Poultry Science, 2(6): 459-464. View at Google Scholar | View at Publisher

Phillips, P.C. and P. Perron, 1988. Testing for a unit root in time series regression. Biometrika, 75(2): 335-346. View at Google Scholar $\mid$ View at Publisher

Presidential Committee on Livestock (PCOL), 2003. Report of the Presidential Committee on Livestock, Consolidated Report, 1.

Rotschild, J., 2002. Nigeria poultry and products poultry update. Gain Report.

Sonaiya, E.B., 1990. The context and prospects for development of small-holder rural poultry production in Africa. Proceedings of the CTA International Seminar, Oct. 9-13. Thessaloniki, Greece. pp: 35-52.

Tijjani, A.A., T. Alimi and A.T. Adesiyan, 2006. Profit efficiency among Nigerian poultry egg farmers: A case study of aiyedoto farm settlement, Nigeria. Research Journal of Agricultural Biological Sciences, 2(6): 256-261. View at Google Scholar

Ume, S.I., P.C. Jiwuba, J.I. Obi and E. Dauda, 2016. Economics of broiler production among rural women in Ahiazu Mbaise L.G.A of Imo State, Nigeria. Asian Research Journal of Agriculture, 1(2): 1-8. View at Publisher

Yusuf, T.M., S.A. Tiamiyu and R.O. Aliu, 2016. Financial analysis of poultry production in Kwara State. Nigeria African Journal of Agricultural Research, 11(8): 718-723. View at Google Scholar | View at Publisher 